\title{
Geochemistry and Petrography of Alkaline rocks from Monte Santo Alkaline Intrusive Suite, Western Araguaia Belt, Tocantins State, Brazil
}

\author{
Rúbia Ribeiro Viana, Gislaine Amorés Battilani \\ Department of Mineral Resource, Federal University of Mato Grosso, Cuiabá, Brazil \\ Email: rrviana@gmail.com, gislaine@ufmt.br
}

Received April 2014

\begin{abstract}
The Monte Santo Alkaline Intrusive Suite (MSAIS) is an association syenite foid, nepheline syenite and syenite. The MSAIS rocks are intruded in metapelites of the Rio do Coco meta-volcanic-sedimentary Sequence and are abundant pegmathoid veins cutting all of them. The mineral paragenesis is represented by aegirina, arfvedsonite, albite and nepheline, crystallized during the initial phase of crystallization. A late magmatic phase show nepheline, perthite, calcite and biotite, and a hydrothermal phase allowed for the formation of cancrinite, sodalite, analcime and natrolita associated with altered nepheline. The geochemical analyses showed metaluminous and medium to high potassium characteristics, being classified as miaskitic rocks, according to agpaicity and the $\mathrm{Na}+\mathrm{K}>1 / 6 \mathrm{Si}$ indexes. However, the mineralogical assemblage suggests a low to medium agpaitic composition, which can be related to a transition from miaskitic to agpaitic crystallization regime. The rare earth elements showed depletion in heavy rare earth and a strong negative Eu anomaly and enrichments in the some lithophile elements, suggesting a differentiated pattern later, which can be associated to metasomatic alterations.
\end{abstract}

\section{Keywords}

Alkaline Rocks, Tocantins Structural Province, Brazil

\section{Introduction}

The alkaline igneous rocks is a general term to describe rocks with high alkali concentrations present, mainly in feldspar, but also in feldspathoids, sodic pyroxenes, sodic amphiboles and other alkali-rich phases. These rocks can be undersaturated in silica which may be either alumina saturated, or undersaturated, corresponding respectively to miaskitic and agpaitic associations. The felsic end-member of these associations is a feldspathoid-bearing syenite or silica (over) saturated peralkaline rocks. The felsic end-members are sodic amphibole and/or aegirine bearing-alkali-feldspar syenite and granite (e.g. Bonin 1998; Fitton \& Upton 1987; Bates \& Jackson 1980; Shand 1922, etc.).

How to cite this paper: Viana, R.R., \& Battilani, G.A. (2014). Geochemistry and Petrography of Alkaline rocks from Monte Santo Alkaline Intrusive Suite, Western Araguaia Belt, Tocantins State, Brazil. Journal of Geoscience and Environment Protection, 2, 72-79. http://dx.doi.org/10.4236/gep.2014.23010 
According to Blichert-Toft et al. 1996 the alkaline rocks generated in the Neoproterozoic and Phanerozoic are scarce and can be found in three main geodynamic settings: (i) continental rifts, (ii) oceanic islands, and (iii) subduction zones (peralkaline granites in back-arc zones). The Ancient alkaline rocks generally are metamorphosed and altered by weathering and/or hydrothermalism which makes their understanding difficult (Blichert-Toft et al. 1996).

Precambrian alkaline rocks are sparsely distributed and outcrop relatively small areas scattered from north to south Brazil. In the Tocantins State, center-west of Brazil, are known three alkaline suites named of Estrela, Peixe and Monte Santo. Few detail studies of the petrogenetic aspect were performed. So, this work is an attempt to characterize the magmatism of the Monte Santo Alkaline Intrusive Suite (MSAIS), based in petrography and geochemical data.

\section{Geological Setting}

The alkaline rocks studied in this work are positioned in the Tocantins Structural Province defined by Almeida (1977) and placed between San Francisco and Amazon cratons. According to Pimentel et al. (2000) the Tocantins Structural Province represents a Brazilian orogen system characterized by belts of folds and thrusts called Brasilia, Paraguay and Araguaia belts, resulting from the convergence and collision of three continental blocks: the Amazon, San Francisco and Paranapanema cratons. The latter covered by rocks of the Paraná Basin (Mantovani \& Brito Neves, 2005). In the study area neoproterozoic and basement rocks are partially covered by phanerozoic sediments of the Parnaíba Basin (Fuck et al., 2001). Paleoproterozoic basement rocks were partially reworked during the Brazilian orogeny (Pimentel et al., 2000).

The basement rocks in the area are represented by the core cratonic rocks with estimated ages between the Archean and Paleoproterozoic. They are composed by a granite-gneiss terrain affected by medium to high metamorphic degree associated with a metavolcanic-sedimentary sequence of the greenschist facies. According to Frasca \& Araújo (2001) the cratonic unit represents the evolution of a portion of the rejuvenated crust re-mobilized and stabilized during the Paleo proterozoic. Structural features suggest a crustal unit independent represented by the Granite-Gneissic Rio dos Mangues Complex and by metavolcano-sedimentary Rio do Coco Sequence.

The rocks of the Granite-Gneissic Rio dos Mangues Complex comprise a medium to high degree metamorphic terrain exposed in the core structure brachyantiform whose lithologies are characterized by igneous rocks of tonalitic-granitic affinity associated with calcium-silicate gneissic rocks showing medium to high metamorphism of amphibolite facies (Frasca \& Araújo, 2001).

The basal portion of the volcano-sedimentary Rio do Coco Sequence is compost by the intercalation of pelitic and chemical metasediments with meta-igneous ultramafic rocks. The upper portion is represented by amphibolite and metasediments. According to Frasca \& Araújo (2001) this sequence was affected by a succession of deformational processes that obliterated primary internal structures and the original contact relation. The deformational processes generated strong transposition foliation and asymmetric isoclinal folds, large-scale folding in open synformes-antiform, crenulations cleavage and faults. Finally the rocks of the area underwent metamorphic processes and intense hydrothermalism.

The alkaline rocks described in the Tocantins State outcrop in the Morro da Estrela near the Porto Nacional city (Marcheto, 1973) and between Paraíso do Tocantins and Monte Santo cities (Cunha et al., 1981). Marcheto (1973) classified the alkaline rocks of Morro da Estrela in litchfieldite leucocratic, coarse-grained, usually displaying sharp banding characterized by alternating dark bands with biotite and light bands with a predominance of feldspars and feldspathoids. Cunha et al. (1981) described alkaline gneisses and nepheline syenite gneiss outcropping about near to Paraiso do Tocantins, in the form of paving stones with metamorphic foliation concordant with the main regional schistosity and suggested a placement of the rocks concomitantly or immediately after the first deformation phase that affected the Estrondo Group. According to Iwanuch (1991) MSAIS is composed of gneisses and alkaline granofels meta-igneous, leucocratic and hololeucocratic, unsaturated, predominantly sodium-persodic, miaskitic and subsolvus with microcline and albite (or oligoclase).

\section{Analytical Techniques}

To geochemical analyses, thirteen alkaline rock samples from MSAIS were prepared by hand to removal of weathered material and after were crushing in a jaw crusher and then milling in a tungsten carbide in the 
LAMUTA/UFMT. Major and trace element contents, including rare earth elements, of these samples were listed in Table 1. Major and trace element were determined at CHEMEX, Canada, by ICP/OES and ICP/MS, respectively. Part of the samples was analyzed also by X-ray fluorescence in the LAMUTA laboratory in the Federal University of Mato Grosso using a Shimadzu fluorescence spectrometer using an automatic sample holder.

\section{Results and Discussion}

\subsection{Petrographic Classification}

Thirteen samples from two different locations of the MSAIS were selected to petrographic description. Field observations showed that the alkaline rocks present a massif structure more to center, gray color and phaneritc fine to medium texture. It is clear the gneiss aspect, mainly in the border, i.e. in the contacts, largely marked by biotite and/or amphibole orientation, showing alternance with felsic bands of nepheline and feldspar.

Table 1. Major and minor (wt\% oxides), trace and rare-earth (ppm) element analyses of rocks from MSAIS.

\begin{tabular}{|c|c|c|c|c|c|c|c|c|c|c|c|c|c|}
\hline & M1 & M3 & M4 & M9 & M10 & M10A & M10B & M11 & M12 & T0S-01N & HP-00 & HTOS & ABX \\
\hline $\mathrm{SiO}_{2}$ & 55.80 & 55.50 & 57.90 & 56.60 & 58.30 & 55.40 & 58.50 & 56.50 & 62.70 & 57.80 & 60.4 & 59.5 & 58.8 \\
\hline $\mathbf{A l}_{2} \mathbf{O}_{3}$ & 21.90 & 20.70 & 23.90 & 21.10 & 20.90 & 23.50 & 20.50 & 21.80 & 20.40 & 22.40 & 19.95 & 21.7 & 19.35 \\
\hline $\mathrm{Fe}_{2} \mathrm{O}_{3}$ & 3.21 & 6.92 & 1.85 & 5.15 & 3.39 & 2.45 & 5.59 & 3.90 & 2.82 & 2.84 & 3.53 & 3.7 & 4.32 \\
\hline $\mathrm{CaO}$ & 1.55 & 0.23 & 0.27 & 0.11 & 0.51 & 0.44 & 1.91 & 0.33 & 0.32 & 0.13 & 0.42 & 0.65 & 1.98 \\
\hline MgO & 0.10 & 0.08 & 0.06 & 0.04 & 0.21 & 0.04 & 0.13 & 0.07 & 0.45 & 0.10 & 0.13 & 0.1 & 0.07 \\
\hline $\mathrm{Na}_{2} \mathrm{O}$ & 8.55 & 6.12 & 8.22 & 8.08 & 7.15 & 10.10 & 8.53 & 8.54 & 6.41 & 10.40 & 8.95 & 8.68 & 6.67 \\
\hline $\mathrm{K}_{2} \mathrm{O}$ & 5.78 & 5.82 & 7.75 & 5.73 & 5.84 & 5.07 & 2.98 & 5.51 & 5.89 & 4.00 & 3.93 & 4.62 & 6.26 \\
\hline $\mathrm{TiO}_{2}$ & 0.06 & 0.08 & nd & 0.02 & 0.08 & 0.02 & 0.09 & 0.05 & 0.08 & 0.07 & 0.09 & 0.07 & 0.06 \\
\hline MnO & 0.12 & 0.19 & 0.05 & 0.19 & 0.10 & 0.04 & 0.07 & 0.09 & 0.08 & 0.05 & 0.08 & 0.1 & 0.15 \\
\hline $\mathbf{P}_{2} \mathbf{O}_{5}$ & nd & 0.09 & 0.01 & $\mathrm{Nd}$ & 0.01 & 0.01 & 0.06 & $\mathrm{Nd}$ & 0.01 & 0.06 & nd & nd & $\mathrm{Nd}$ \\
\hline SrO & 0.01 & 0.01 & 0.02 & Nd & 0.02 & nd & 0.04 & $\mathrm{Nd}$ & 0.01 & $\mathrm{Nd}$ & 0.01 & nd & 0.01 \\
\hline BaO & 0.03 & 0.02 & 0.01 & $\mathrm{Nd}$ & 0.04 & 0.01 & 0.07 & 0.02 & $\mathrm{Nd}$ & 0.02 & 0.04 & 0.01 & 0.02 \\
\hline LOI & 1.62 & 1.42 & 0.46 & 0.54 & 0.90 & 0.65 & 0.57 & 0.48 & 0.63 & 0.41 & 0.99 & 0.96 & 1.86 \\
\hline Total & 98.70 & 97.20 & 100.50 & 97.60 & 97.50 & 97.70 & 99.00 & 97.30 & 99.80 & 98.30 & 98.5 & 100 & 99.6 \\
\hline Ba & 275.0 & 165.5 & 455.0 & 18.1 & 380.0 & 72.9 & 621.0 & 210.0 & 268.0 & 208.0 & 358.0 & 68.0 & 136.0 \\
\hline $\mathbf{R b}$ & 307.0 & 356.0 & 331.0 & 656.0 & 302.0 & 238.0 & 76.9 & 315.0 & 261.0 & 188.5 & 192.5 & 253.0 & 272.0 \\
\hline $\mathrm{Sr}$ & 77.0 & 49.0 & 108.0 & 17.2 & 140.5 & 25.6 & 361.0 & 36.2 & 138.0 & 32.1 & 104.0 & 39.9 & 60.8 \\
\hline $\mathbf{Y}$ & 9.8 & 11.0 & 1.2 & 1.6 & 1.6 & 2.7 & 6.7 & 2.2 & 2.7 & 1.2 & 1.9 & 2.2 & 5.8 \\
\hline $\mathrm{Zr}$ & 110.0 & 218.0 & 32.0 & 735.0 & 1320.0 & 127.0 & 249.0 & 183.0 & 55.0 & 94.0 & 184.0 & 194.0 & 209.0 \\
\hline Nb & 30.6 & 150.5 & 37.8 & 162.5 & 94.8 & 22.7 & 81.7 & 69.5 & 48.3 & 69.8 & 85.6 & 68.1 & 91.7 \\
\hline Th & 2.4 & 2.0 & 1.3 & 1.5 & 4.6 & 3.1 & 6.0 & 1.3 & 5.6 & 0.5 & 3.2 & 0.7 & 1.2 \\
\hline $\mathbf{P b}$ & nd & nd & 10.0 & 5.0 & 9.0 & nd & 7.0 & $\mathrm{Nd}$ & 14.0 & $\mathrm{Nd}$ & 6.0 & 48.0 & $\mathrm{Nd}$ \\
\hline Ga & 20.5 & 19.8 & 19.4 & 40.1 & 22.0 & 20.4 & 21.8 & 23.3 & 21.2 & 19.8 & 17.3 & 18.5 & 18.5 \\
\hline Zn & 43.0 & 116.0 & 25.0 & 166.0 & 59.0 & 21.0 & 55.0 & 78.0 & 49.0 & 54.0 & 78.0 & 71.0 & 71.0 \\
\hline Hf & 2.7 & 5.5 & 0.7 & 13.9 & 25.1 & 2.4 & 5.4 & 3.4 & 1.3 & 2.0 & 3.4 & 2.8 & 4.6 \\
\hline Cs & 1.1 & 2.8 & 1.1 & 4.2 & 2.3 & 0.5 & 0.5 & 1.2 & 1.7 & 1.1 & 1.5 & 1.9 & 1.4 \\
\hline Ta & 1.4 & 5.7 & 1.4 & 14.3 & 9.5 & 1.2 & 6.1 & 4.5 & 3.2 & 1.8 & 2.4 & 2.0 & 5.4 \\
\hline Co & 38.2 & 38.2 & 51.1 & 80.1 & 52.7 & 79.4 & 78.8 & 39.3 & 40.4 & 61.4 & 44.8 & 29.5 & 40.6 \\
\hline $\mathbf{U}$ & 0.4 & 0.6 & 0.2 & 5.7 & 9.3 & 0.5 & 2.1 & 1.0 & 1.6 & 0.7 & 0.5 & 1.0 & 2.6 \\
\hline $\mathbf{W}$ & 236.0 & 209.0 & 298.0 & 496.0 & 279.0 & 375.0 & 416.0 & 243.0 & 249.0 & 306.0 & 205.0 & 138.0 & 202.0 \\
\hline Sn & 2.0 & 4.0 & 1.0 & 3.0 & 2.0 & 1.0 & 4.0 & 2.0 & 2.0 & 1.0 & 2.0 & nd & 2.0 \\
\hline La & 37.40 & 49.30 & 6.10 & 2.40 & 12.80 & 24.20 & 37.10 & 7.50 & 18.90 & 5.30 & 11.2 & 4.4 & 20.1 \\
\hline Ce & 56.20 & 89.70 & 9.00 & 3.60 & 19.80 & 32.70 & 55.20 & 11.80 & 18.00 & 9.30 & 14.9 & 14.7 & 34.2 \\
\hline Pr & 4.93 & 9.39 & 0.86 & 0.32 & 1.73 & 2.67 & 5.88 & 1.06 & 2.18 & 0.93 & 1.25 & 1.2 & 3.53 \\
\hline Nd & 13.70 & 29.30 & 2.40 & 0.90 & 4.80 & 7.10 & 17.60 & 3.00 & 6.10 & 3.00 & 3.6 & 3.4 & 10.8 \\
\hline Sm & 1.87 & 3.97 & 0.29 & 0.10 & 0.47 & 0.81 & 2.50 & 0.40 & 0.82 & 0.38 & 0.43 & 0.46 & 1.55 \\
\hline Eu & 0.40 & 0.45 & 0.09 & 0.03 & 0.20 & 0.16 & 0.46 & 0.08 & 0.27 & 0.05 & 0.12 & 0.1 & 0.19 \\
\hline Gd & 2.09 & 4.10 & 0.37 & 0.15 & 0.51 & 0.93 & 2.54 & 0.46 & 0.94 & 0.42 & 0.45 & 0.44 & 1.47 \\
\hline Tb & 0.27 & 0.49 & 0.04 & 0.02 & 0.04 & 0.10 & 0.32 & 0.06 & 0.12 & 0.04 & 0.06 & 0.06 & 0.2 \\
\hline Dy & 1.59 & 2.45 & 0.21 & 0.19 & 0.22 & 0.50 & 1.53 & 0.38 & 0.63 & 0.26 & 0.34 & 0.28 & 1.17 \\
\hline Ho & 0.36 & 0.47 & 0.04 & 0.05 & 0.07 & 0.10 & 0.30 & 0.08 & 0.13 & 0.05 & 0.08 & 0.06 & 0.25 \\
\hline Er & 1.27 & 1.49 & 0.15 & 0.23 & 0.36 & 0.36 & 0.92 & 0.33 & 0.41 & 0.16 & 0.23 & 0.31 & 0.79 \\
\hline $\mathbf{T m}$ & 0.22 & 0.23 & 0.03 & 0.06 & 0.08 & 0.06 & 0.15 & 0.06 & 0.07 & 0.04 & 0.04 & 0.07 & 0.13 \\
\hline Yb & 1.72 & 1.75 & 0.17 & 0.50 & 0.81 & 0.38 & 1.15 & 0.48 & 0.46 & 0.19 & 0.37 & 0.45 & 0.95 \\
\hline Lu & 0.31 & 0.31 & 0.03 & 0.10 & 0.17 & 0.07 & 0.23 & 0.09 & 0.07 & 0.03 & 0.07 & 0.08 & 0.18 \\
\hline
\end{tabular}


The principal mineralogy is represented by alkali-feldspar (30\% to 53\%, orthoclase and microcline), plagioclase ( $14 \%$ to $58 \%$, oligoclase to albite), biotite ( $7 \%$ to $21 \%$ ) and feldspathoid ( $2 \%$ to $38 \%$, nepheline and/or sodalite), aegirine $(0 \%-1 \%)$ and amphibole $(0 \%-2 \%$, arfvedsonite). It is common the presence of perthite and antiperthite intergrowth. Apatite, corindon, epidote, titanite, zircon and opaque minerals are accessory minerals, while the secondary minerals are calcite, cancrinite, chlorite, muscovite, and zeolites (analcime and natrolite). Cancrinite and calcite can be present in quantify higher $30 \%$ in some samples.

The mineral paragenesis (Figure 1) show early magmatic arfvedsonite + albite + nepheline, followed by later magmatic nepheline + perthite + calcite + biotite, and later hydrothermal cancrinite + sodalite + analcime + natrolita associated with altered nepheline. Zirkel (1866, in Fall et al. 2007) introduced the term ditroite to designate biotite, nepheline and sodalite-bearing syenites, compound of sodalite, calcite and cancrinite, occurring as one of the main rock components of the Ditrău alkaline intrusive massif in the East Carpathians, Hungary. Mitchell (1996) suggested the term hypersolvus sodalite nepheline syenite for rocks with the same mineral composition.

Pegmathoid veins cutting this suite are common. These veins show irregular shape and contain sodalite, feldspar (microcline/ortoclase and albite) and cancrinite as principal mineralogy. The post magmatic processes that controlled the mineralogical modifications of these rocks were mainly hydrothermal metasomatic processes that can also have been responsible by pegmathoid formation.

\subsection{Lithogeochemical Character}

Alkaline rocks can be subdivided into metaluminous $\left[\left(\mathrm{Na}_{2} \mathrm{O}+\mathrm{K}_{2} \mathrm{O}\right)<\mathrm{Al}_{2} \mathrm{O}_{3}<\left(\mathrm{CaO}++\mathrm{Na}_{2} \mathrm{O}+\mathrm{K}_{2} \mathrm{O}\right)\right]$ and peralkaline $\left[\left(\mathrm{Na}_{2} \mathrm{O}+\mathrm{K}_{2} \mathrm{O}\right)>\mathrm{Al}_{2} \mathrm{O}_{3}\right]$ types, based on the molar ratios of $\mathrm{Na}_{2} \mathrm{O}+\mathrm{K}_{2} \mathrm{O}$ relative to $\mathrm{Al}_{2} \mathrm{O}_{3}$ (Streckeisen \& Hunziker 1974; Sørensen, 1974, Shand 1922, Frost \& Frost 2008). Shand (1922) divided alkaline rocks into two categories: i) Miaskitic rocks, with $\mathrm{K}+\mathrm{Na}<\mathrm{Al}, \mathrm{K}+\mathrm{Na}>1 / 6 \mathrm{Si}$ and ii) Agpaitic rocks, with $\mathrm{K}+\mathrm{Na}>\mathrm{Al}$, $\mathrm{K}+\mathrm{Na}<1 / 6 \mathrm{Si}$. Sometimes the peralkaline term is used as synonymous of agpaitic, what is incorrect, according to Le Maitre (2002), even as agpaitic term can be used for rocks containing eudialyte, aegirine, and arfvedsonite minerals. So, a rock can be considered peralkaline-agpaitic if the $\mathrm{Al}_{2} \mathrm{O}_{3}$ content (in molecular proportions) is less than the sum of potassium and sodium oxides.

The geochemical data of the studied rocks are summarized in Table 1, whose results allowed to characterize the rocks of the MSAIS as metaluminous and potassic, based in the ratios $\mathrm{Al}_{2} \mathrm{O} /\left(\mathrm{K}_{2} \mathrm{O}+\mathrm{Na}_{2} \mathrm{O}\right)>1$.

The alkali-alumina relationships i.e. the agpaicity index $(\mathrm{Na}+\mathrm{K}) / \mathrm{Al})$ ) classified the alkaline rocks studied as miaskitic which varies between 0.81 and 0.99 , confirmed by the $\mathrm{Na}+\mathrm{K}>1 / 6 \mathrm{Si}$ indexes, according to researcher studies (Ussing 1911; Shand 1922; Streckeisen \& Hunziker 1974; Sørensen 1974; Fall 2005). The mineralogical assemblage described, suggest also a low to medium agpaitic composition, according to Khomyakov (1995) classification, showed by geochemical composition in terms of contents of $\mathrm{Zr}, \mathrm{Hf}, \mathrm{Nb}$, and $\mathrm{Ta}$. Ta and Nb contents probably are present in mica, whereas $\mathrm{Zr}$ and $\mathrm{Hf}$ are represent the zircons. Agpaitic magmas can be derives from miaskiitic magmas, although there is a mineralogical transition between miaskitic and agpaitic syenites

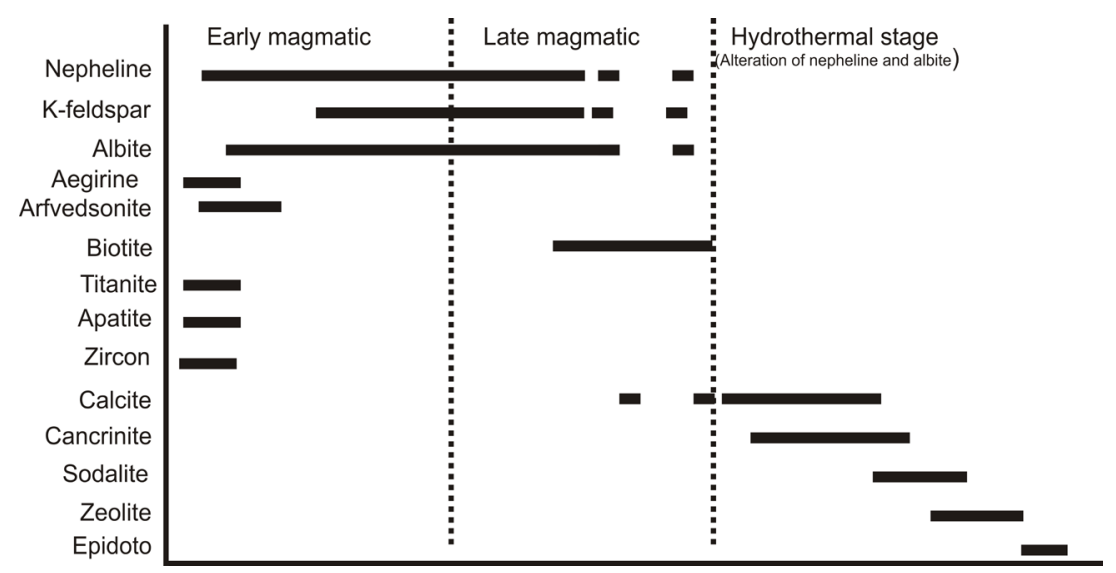

Figure 1. Minerals Paragenesis of major rocks forming minerals in nepheline syenites of the MSAIS rocks. 
(Carmichael et al., 1974, Ulbrich, 1984, Sorensen 1997). This mineralogical transition in the data from MSAS can be observed in the alkali vs. silica diagram Figure 2.

The modification from miaskitic to agpaitic crystallization regime, extremely discussed by Marks et al. (2011) can occur by the extraction of rock-forming minerals.

The formation K-feldspar or K-feldspar and nepheline can derivate a magmatic sodic trend, whereas the fractionation of nepheline and/or aegirine/arfvedsonite a potassic trend. The agpaicity index less than one to MSAIS suggest miaskitic magma and the mineralogical assemblage represented by sodalite, arfvedsonite, apatite, etc., suggest agpaitic magma. According to Sørensen (1997) the transitional rocks between agpaitic and miaskitic should therefore be distinguished as a separate group of rock and, so we chose by the nepheline syenite term.

The most samples of the MSAIS rocks can be classified as nepheline syenite and syenite fields, showing character medium to high potassium as seen on the $\mathrm{SiO}_{2} \mathrm{X} \mathrm{K}_{2} \mathrm{O}$ and $\mathrm{Na}_{2} \mathrm{O} \mathrm{X} \mathrm{K} \mathrm{K}_{2} \mathrm{O}$ relationship Figure 3.

Major and trace elements (Figure 4) divided the samples into two trends, showed mainly in terms of $\mathrm{SiO}_{2}$ against $\mathrm{K}_{2} \mathrm{O}, \mathrm{Na}_{2} \mathrm{O}, \mathrm{Fe}_{2} \mathrm{O}_{3}, \mathrm{BaO}$, $\mathrm{Zn}$ and $\mathrm{Rb}$. Regarding the trace elements, $\mathrm{Nb}$ and $\mathrm{Zn}$ increase whereas $\mathrm{Rb}$ and Ba decrease with increasing $\mathrm{SiO}_{2}$ content. These correlations suggest that the $\mathrm{SiO}_{2}$ increase by fractionation crystallization was not so expressive to nepheline syenite magma that originated the MSAIS. However in the binaries graphics, main $\mathrm{Al}_{2} \mathrm{O}_{3}$ versus $\mathrm{Na}_{2} \mathrm{O}$ is observed a positive correlation, suggesting nepheline and/or plagioclase fractionation, and a weak positive correlation against $\mathrm{K}_{2} \mathrm{O}$, pointing out some fractionation of nepheline and/or potassic alkaline feldspar.

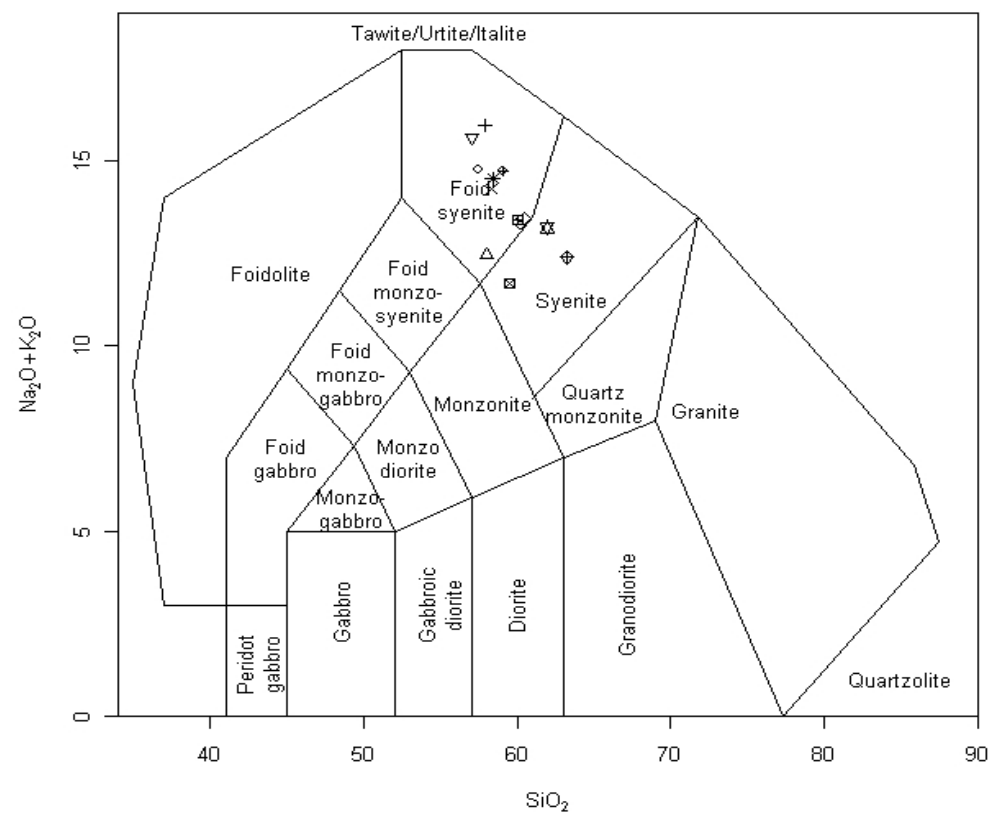

Figure 2. TAS diagram classification of MSAIS rocks in the total alkali-silica diagram (Middlemost, 1985).

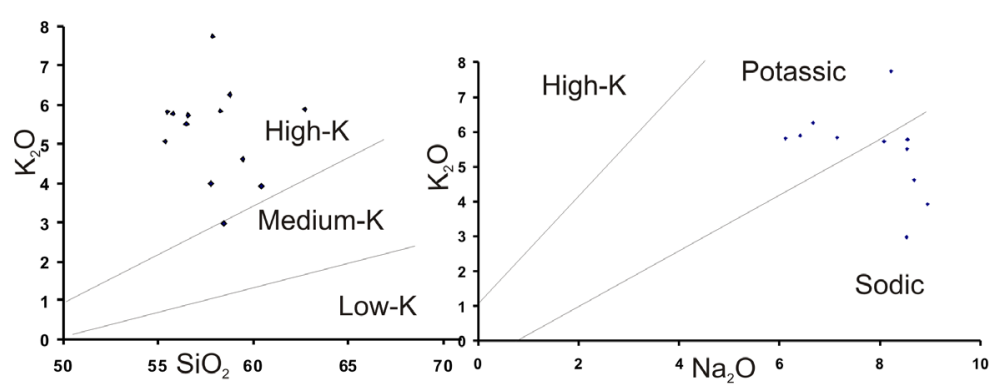

Figure 3. $\mathrm{SiO}_{2} \mathrm{X} \mathrm{K} \mathrm{K}_{2} \mathrm{O}$ and $\mathrm{Na}_{2} \mathrm{O}$ X K $\mathrm{K}_{2} \mathrm{O}$ diagrans (Middlemost, 1975), showing that the MSAIS samples are ultrapotassic to sodic. 

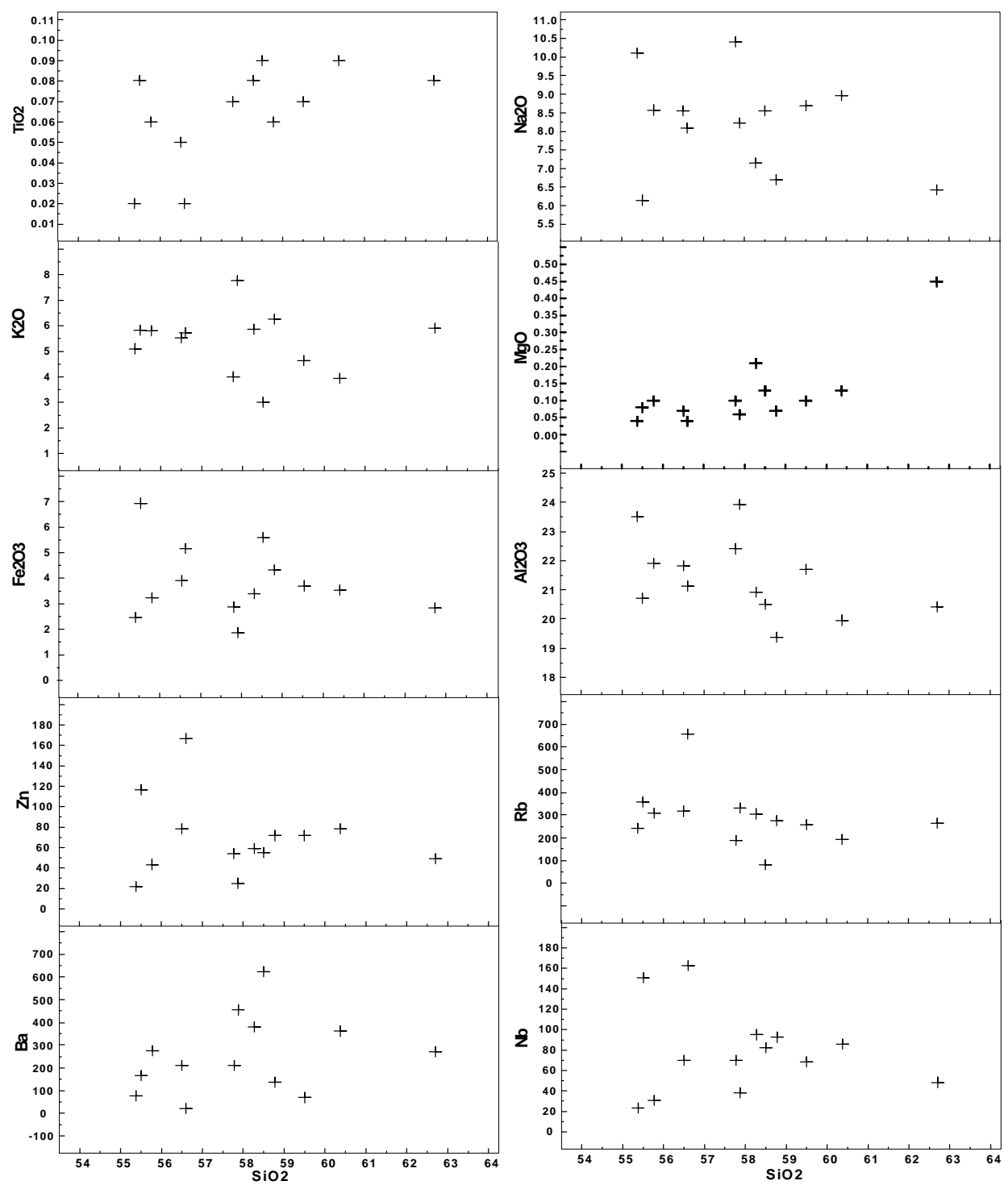

Figure 4. Variation diagram between $\mathrm{SiO}_{2}$ against some oxides and trace elements.

The REE diagram normalized to Condrite-Nakamura (1974) for the MSAIS rocks showed depletion in heavy rare earth and a strong negative Eu anomaly (Figure 5). Almost all samples showed REE patterns similar, although it is evidenced two groups with different REE elements concentrations. Only one sample (M10) showed a discrete positive Eu anomaly, which can be explained by the presence of aegirine and arfvedsonite.

Consistent features of nepheline syenite of MSAIS spidergrams (Figure 5) are marked depletions at Y, Ti, Th, and $U$ and (HREE) and a enrichments in the some lithophile elements (LILE and LREE). These data suggest a differentiated pattern later that can be associated to metasomatic alterations. The geochemical characteristics of the studied rocks are consistent with an intraplate tectonic setting, as viewed, on the Rb vs. Y + Nb (Figure 6) of the diagrams of Pearce et al. (1984).

\section{Conclusions}

Various processes of metasomatism, such as biotitization, albitization, and nephelinization seem to control the prevailing appearance of these rocks, as soon as magmatic stages of their development.

The results obtained suggest that metasomatic alterations can have been involved in formation of alkaline rocks, including pegmatites as soon as in modification from miaskiticas to agpaitic rocks. 

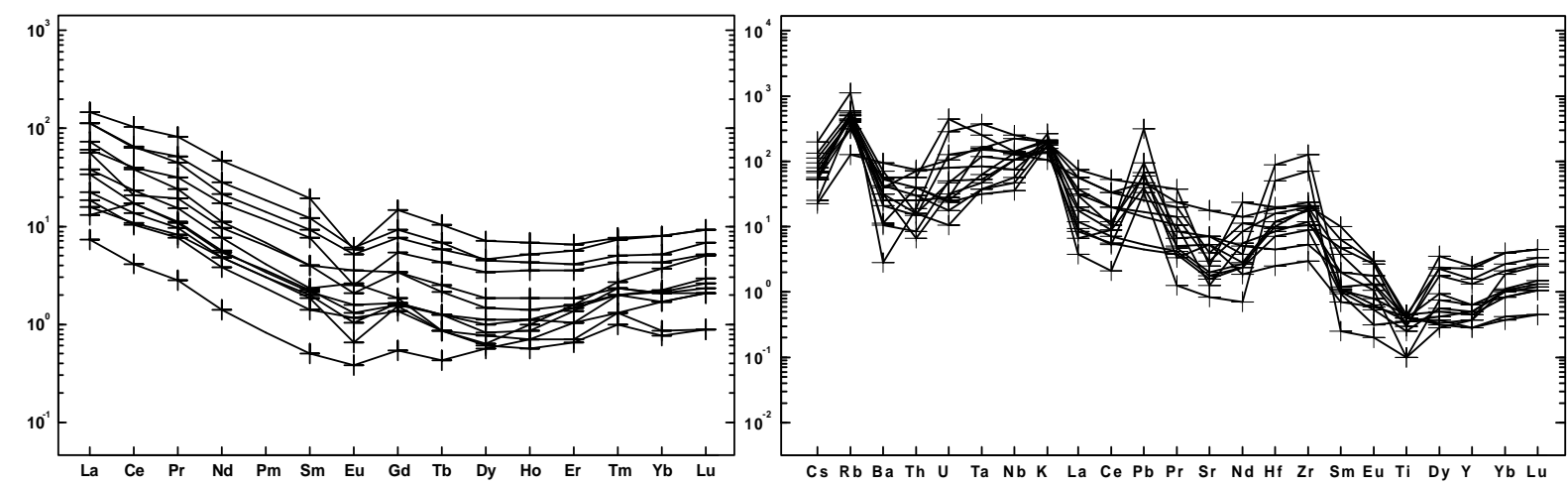

Figure 5. Chondrite normalized (Nakamura 1974) REE patterns and Primordial Mantle (McDonough \& Sun 1995) to rocks of MSAIS.

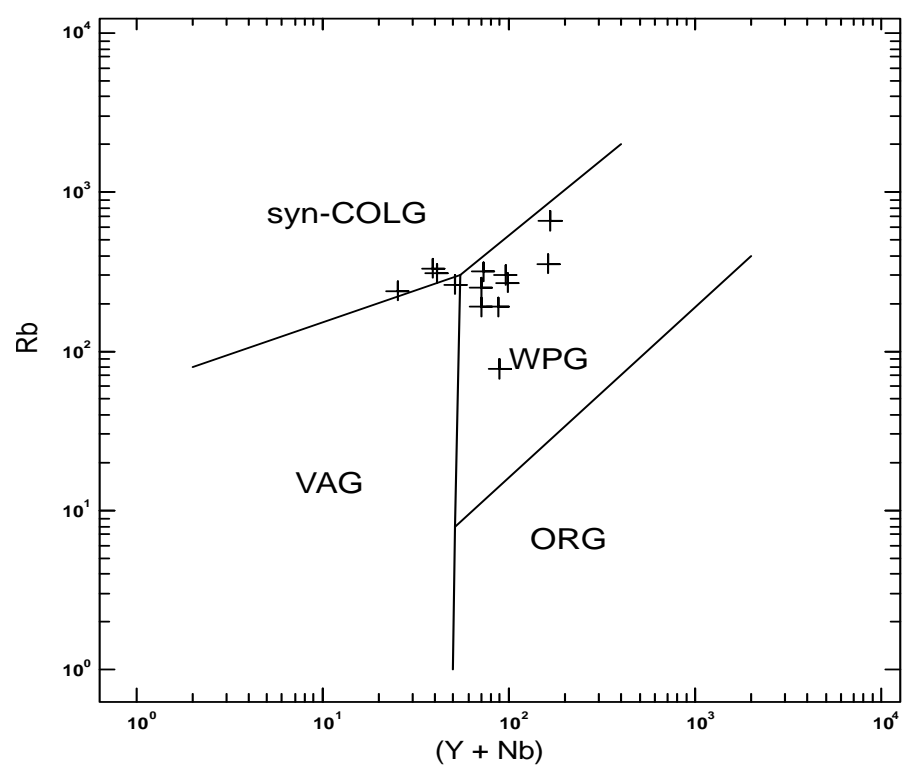

Figure 6. $\mathrm{Rb} \mathrm{X}(\mathrm{Y}+\mathrm{Nb})$ plot, showing intraplate environment to rocks of the MSAIS (after Pearce et al. 1984).

For a better understanding spatial, textural, mineralogical and geochemical from the miaskitic to agpaitic crystallization regime, there will be need a detailed mapping with systematic sampling of the entire complex and their respective analyses.

\section{Acknowledgements}

This work was partially supported by the Foundation for Research Support of the State of Mato Grosso (FAPEMAT) and National Scientific and Technological Development Council (CNPQ).

\section{References}

Almeida, F. F. M., Hasui, Y. and Brito Neves, B. B., \& Fuck R. A. (1977). Províncias Estruturais Brasileiras. In: VIII Simpósio de Geologia do Nordeste, Campina Grande. Atas. Pernanbuco, SBG-Núcleo Nordeste, 1, 363-392.

Bates, R. L., \& Jackson, J. A. (1980). Glossary of Geology. AGI, Falls Church, 751 p.

Shand, S. J. (1922). The Problem of the Alkaline Rocks. Proceedings of the Geological Society of South Africa, 25, 19-33.

Blichert-Toft, J., Arndt, N. T., \& Ludden J. N. (1996). Precambrian Alkaline Magmatismo. Lithos, 37, 97-111.

http://dx.doi.org/10.1016/0024-4937(95)00031-3

Bonin, B., Azzouni-Sekkal, A., Bussy, F., \& Ferrag, S. (1998). Alkali-Calcic and Alkaline Post-Orogenic (PO) Granite 
Magmatism: Petrologic Contraints and Geodynamic Setting. Lithos, 45, 45-70.

http://dx.doi.org/10.1016/S0024-4937(98)00025-5

Carmichael, I. S. E, Turner, F. J., \& Verhoogen, J. (1974). Igneous Petrology. McGraw-Hill, New York

Ulbrich, H.H. (1984). A Petrografia, a Estrutura e o Quimismo de Nefelina Sienitos do Maciço Alcalino de Poços de Caldas, MG-SP. Ph.D. Dissertation, Inst. De Geociências, Univ. São Paulo, 477 p.

Cunha, B. C. C., Potiguar, L. A. T., Lanhez, A. C., Bezerra, P. E. L., Pitham, J. H. L., Souza, Jr., J. J., \& Tassinari, C. C. G. (1981). Geologia, Geomorfologia, Pedologia, Vegetação r uso potencial da Terra. Brasil. Projeto RADAMBRASIL. Folha SC.22 Tocantins. Rio de Janeiro, (Levantamento de Recursos Naturais, 22), 21-196.

Fall, A. (2005). Fluid Evolution in the Nepheline Syenites of the Ditrău Alkaline Massif, Transylvania, Romania. Ph.D. Dissertation, Blacksburg, Virginia, Faculty of the Virginia Polytechnic Institute and State University.

Fall, A., Bodnar, R.J., Sszabõ, C. and Pal-Molnãr, E. (2007). Fluid Evolution in the Nepheline Syenites of the Ditrau Alkaline Massif, Transylvania, Romania. Lithos, 95, 331-345. http://dx.doi.org/10.1016/j.lithos.2006.08.005

Fitton, J. G., \& Upton, B. G. (1987). Alkaline Igneous Rocks. Geol. Soc. Spec. Publ. 30. 568 p.

Frasca, A. A .S., \& Araújo, V. A. (2001). Projeto Hidrogeologia no Tocantins—Folha Palmas—SD 22-Z-B. CPRM/Serviço Geológico do Brasil, Goiânia, 52 p.

Frost, B. R., \& Frost, C. D. (2008). A Geochemical Classification for Feldspathic Igneous Rocks. Journal of Petrology, 49, 1955-1969. http://dx.doi.org/10.1093/petrology/egn054

Fuck, R. A., Dantas, E. L., Pimentel, M. M., Junges, S. L., \& Moraes, R. (2001). Nd Isotopes, U-Pb Single Grain and SHRIMP Zircon Ages from Basement Rocks of the Tocantins Province. Proceedings of the III South American Symposium on Isotope Geology, Extended Abstract, Santiago, 141-144 (CD ROM).

Iwanuch, W. (1991). Geologia dos complexos alcalinos proterozóicos do centro do estado de Tocantins. Ph.D. Dissertation, Instituto de Geociências, Universidade de São Paulo, São Paulo.

Khomyakov, A. P. (1995). Mineralogy of Hyperagpaitic Alkaline Rocks (p. 223). Oxford: Clarendon Press.

Le Maitre, R. W. (2002). Igneous rocks a Classification and Glossary of Terms Recommendations of the International Union of Geological Sciences, Sub-Commission on the Systematics of Igneous Rocks, Cambridge University Press, 236 p. http://dx.doi.org/10.1017/CBO9780511535581

Mantovani, M. S. M., \& Brito Neves, B. B. (2005). The Paranapanema Lithospheric block: Its Importance for Proterozoic (Rodinia, Gondwana) Supercontinent theoRies. Gondwana Research, 8, 303-315. http://dx.doi.org/10.1016/S1342-937X(05)71137-0

Marcheto, C. M. L. (1973). Nota Sobre a Ocorrência de um Litechfieidito no Morro da Estrucei, Município de Porto Nacional, Goiás. Congresso Brasileiro de Geologia, Resumo das Comunicações. Soe. Bras. Geologia, Bol. 1, pp. 85-86.

Marks, M. A. W., Hettmann, K., Schilling, J., Frost, B. R., \& Markl, G. (2011). The Mineralogical Diversity of Alkaline Igneous Rocks: Critical Factors for the Transition from Miaskitic to Agpaitic Phase Assemblages. Journal of Petrology, 52, 439-455. http://dx.doi.org/10.1093/petrology/egq086

McDonough, W. F., \& Sun, S.-S. (1995). The Composition of the Earth. Chemical Geology, 120, 223-253. http://dx.doi.org/10.1016/0009-2541(94)00140-4

Middlemost, E. A. K. (1975) The Basalt Clan. Earth Science Reviews, 11, 337-364. http://dx.doi.org/10.1016/0012-8252(75)90039-2

Middlemost, E. A. K. (1985). Magmas and Magmatic Rocks. Longman Group Limited, Essex, UQ.

Mitchell, R. H. (1996). Perovskites: A Revised Classification Scheme for an Important Rare Earth Element Host in Alkaline Rocks. In Jones, A. P., Wall, F., \& Williams, C. T. (Eds.), Rare Earth Minerals: Chemistry, Origin and Ore Deposits (pp. 41-76). London: Chapman \& Hall.

Streckeisen, A., \& Hunziker, I. C. (1974). Schweiz. Mineral. Petr. Mitt., 54, 59-77.

Nakamura, N. (1974). Determination of REE, Ba, Fe, Mg, Na, and K in Carbonaceous and Ordinary Chondrites. Geochimica et Cosmochimica Acta, 38, 757-775

Pearce, J. A., Harris, N. B. W., \& Tindle, A. J. (1984). Trace Element Discrimination Diagrams for the Tectonic Interpretation of Granitic Rocks. Journal of Petrology, 25, 956-83.

Pimentel, M. M., Fuck, R. A., Jost, H., Ferreira Filho, C. F., \& Araújo, S .M. (2000). The Basement of the Brasília Fold Belt and the Goiás Magmatic Arc. In: Cordani, U. G., Milani, E. J., Thomaz Filho, A. and Campos, D. A. (Eds.), Tectonic Evolution of South America (pp. 190-229), Rio de Janeiro: 31st IGC.

Sørensen, H. (1974). Alkali Syenites, Feldspathoidal Syenites and Related Lavas. In Sorense, H. (Ed.), The Alkaline Rocks (pp. 22-52), London: John Wiley \& Sons.

Sorensen, H. (1997). The AGPAITIC rocks-An Overview. Mineralogical Magazine, 61, 485-498. 